S.Afr. Tydskr. Landbouvoorl./S. Afr. J. Agric. Ext.,

Vol. 43, No. 2, 2015: $78-90$

DOI: http://dx.doi.org/10.17159/2413-3221/2015/v43n2a358
Odunze, Van Niekerk

\& Ndlovu.

(Copyright)

\title{
ASSESSMENT OF FACTORS THAT IMPACT ON THE VIABILITY OF CONTRACT FARMING: A CASE STUDY OF MAIZE AND SOYA BEANS IN MASHONALAND WEST AND CENTRAL PROVINCES IN ZIMBABWE
}

\author{
Odunze, D., ${ }^{17}$ Van Niekerk, J. A. ${ }^{18} \&$ Ndlovu, S. ${ }^{19}$ \\ Correspondence Author: J A van Niekerk. Email: vNiekerkJA@ufs.ac.za
}

\begin{abstract}
This research analyses factors that affect the viability of contract farming in the Zimbabwean maize and soya sector. The objective was to analyse how sustainability factors (social, ethical, environmental and economic factors) were integrated to ensure the viability and sustainability of contract ventures. A sample of 70 farmers and 4 contracting firms involved in the contract farming production of maize and soya were used. A questionnaire survey and focus group interviews were used as data gathering tools. Quantitative and qualitative data analysis techniques were used and a probit regression model was applied to identify the factors that impacts significantly on the viability of the enterprises. The farmer's scale, years of experience, availability of inputs, crop grown, production area and access to finances were all identified as the significant factors affecting contract farming viability. It was recommended that farmers refrain from side marketing and contractors stick to contractual agreements in terms of payments and timely provision of inputs.
\end{abstract}

Keywords: contract farming; viability; sustainability

\section{INTRODUCTION}

Contract farming is not a new concept, it was used in the $19^{\text {th }}$ century in Asia and Latin America. In the $20^{\text {th }}$ century it spread in Europe and United States then eventually introduced in North and Sub-Saharan Africa (Kirsten \& Sartorius, 2002). It is an agreement between a producer (farmer) and the integrator (agribusiness firm) which involves the lending of seeds, fertilizer, pesticides and many other inputs with specific marketing arrangements (Prowse, 2012; FAO, 2013). According to Costales \& Catelo (2008), the agreement between the two parties must specify price, quality, quantity, delivery requirements and remuneration for work done.

Adoption rates in the past decade has increased, examples include United States which rose from $12 \%$ in 1969 to $36 \%$ in 2004, in Brazil $75 \%$ of poultry is produced under contracts and policies that support contract farming have been developed in Vietnam, India, Thailand, and Morocco (Will, 2013). In southern Africa it is now receiving more attention as an effort from governments to commercialize smallholder agriculture in order to improve incomes and livelihoods of small scale farmers and also create employment (Shoja, Rani 2007). Grain maize production in Malawi, sugarcane schemes in Swaziland, South Africa and Zimbabwe and horticultural schemes in Zambia and Zimbabwe are some of the successful examples of

\footnotetext{
${ }^{17}$ M-student, Centre for Sustainable Agriculture, Rural Development and Extension, University of the Free State, Bloemfontein 9300, South Africa

${ }^{18}$ Director, Centre for Sustainable Agriculture, Rural Development and Extension, University of the Free State, Bloemfontein 9300, South Africa. Email: vNiekerkJA@ufs.ac.za

${ }^{19} \mathrm{M}$-student, Centre for Sustainable Agriculture, Rural Development and Extension, University of the Free State, Bloemfontein 9300, South Africa
} 
S.Afr. Tydskr. Landbouvoorl./S. Afr. J. Agric. Ext.,

Vol. 43, No. 2, 2015: $78-90$

DOI: http://dx.doi.org/10.17159/2413-3221/2015/v43n2a358
Odunze, Van Niekerk

\& Ndlovu.

(Copyright)

contract farming in the region (Woodend, 2003). Contract farming is set to be more important following emphasis from governments, donors and development agencies on a private sector led approach to development.

The last two decades have seen market liberalization in most African countries, Zimbabwe included. This resulted in eliminating state monopolies and encouraged private sector activities in production to improve competitiveness and efficiency in markets. Linkages between markets and smallholder farmers have not developed in an anticipated way since the collapse of parastatal companies (NEPAD 2008). Attributing factors include limited knowledge of potential markets by smallholder farmers, lack of credit for required equipment and lack of access to technical advice on standards. Failure by smallholder farmers to participate and compete in the liberalized economy led to the promotion of contract farming.

According to Scoones (2012), Contracting arrangements have proved to be a positive solution to a large extent in Zimbabwe, especially as it draws new entrepreneurs with new finance and skills into the sector, reshaping economic and political relationships and spreading the gains of land reform in new ways. However past experiences show the need to be cautious but with the economy just barely beginning to recover, it's certainly a trend worth tracking. Although the strategy is innovative, a lot of contractors have in the past experienced low recovery rates on their investments and some have incurred losses in the contract farming venture due to side marketing by the contracted farmers. Farmers on the other hand have experienced what they call exploitation from the contractors. It has been realized that most farmers enter into contractual agreements without adequate knowledge on the inputs and producer prices being offered. The slow recovery rates and high probabilities of contractual default expose the existence of sustainability hindrances which need to be clearly understood then appropriately addressed.

There is currently no established legislative framework to promote contract farming in Zimbabwe across all agricultural commodities as the Ministry of Agriculture, Mechanization and Irrigation is still consulting stakeholders to come up with an enabling framework. There is indeed no doubt about the need to improve modalities of contract farming in Zimbabwe in a way that ensures that both the farmer and contractor benefits leading to sustainability of the agricultural sector. This study therefore endeavours to investigate the balance of play among the social, ethical, economic, ecological and productivity factors associated with this practice and their effects on the Zimbabwean farming communities. The study will also attempt to identify and recommend best practices for contract farming that will ensure long term sustainability and increased market competitiveness for the newly evolving Zimbabwean farming sector.

\subsection{Challenges for contract farming in Zimbabwe}

According to Porter \& Phillips-Howard (1997), contract farming is seen as a tool of modernization and integrates emerging farmers into export markets. In Zimbabwe there is an increased number of small scale farmers following the fast track land reform program which transferred over $90 \%$ of the commercial white owned farms to local small holder farmers. Dawes Murota, Jera, Masara, \& Sola (2009) states that the resettled farmers lack basic inputs like seed, fertilizers, transport to take their produce to the market and farm equipment. Given the present scenario in the country contract farming is of great benefit to small scale farmers. Contract farming is sometimes exploitative in nature because most agribusinesses enjoy an unequal bargaining position with farmers (Parirenyatwa \& Mago, 2014; Little \& Watts 1994, 
S.Afr. Tydskr. Landbouvoorl./S. Afr. J. Agric. Ext.,

Vol. 43, No. 2, 2015: $78-90$

DOI: http://dx.doi.org/10.17159/2413-3221/2015/v43n2a358
Odunze, Van Niekerk

\& Ndlovu.

(Copyright)

Masakure \& Henson, 2005). Clapp (1994) evaluated contract farming schemes in Africa and concluded that the "the contracted farmer is sometimes reduced to little more than a hired hand." Other problems include late payments, lack of technical support and unreasonable raise in quality standards. Farmers also face weak claiming position in-case whereby the buyer defaults and they are stuck with produce. Similarly contractors on the other hand face problems of being frustrated by farmers who divert inputs and sell produce to open markets if price is higher than agreed price (Pandit, Pandey, Rana, \& Lal, 2009).

A multiplicity of factors including social, economic, ethical, ecological and others contribute to this diversity. Social factors which involve literacy level of farmers, gender preference, bias towards larger farms by contractors, tenure security and increased labour burden on the farmer need to be investigated to examine their bearing on viability of contract farming. Ecological factors which include suitability of the area to production of a particular area and use of environmentally sustainable farming practices and economic factors which include lack of financing from banks and credit institutions, prevailing interest rates charged by banks to contractors for loans and low profit levels on both sides due to high production costs also need to be addressed. There is therefore a need for an in-depth study that will provide an accurate assessment of factors contributing to the compromised viability of contract farming in Zimbabwe.

There is also no clarity on the role being played by government in contract farming in Zimbabwe in ensuring that the interest of both parties is protected. Poor coordination and conflicting demands by farmer organisations may also be a factor that have hinders the viability of the contract ventures. Also of importance is the extent of the relationship existing between the farmers, contractors and other linkage partners like transporters, stockers, and extension or training officers. Currently, there is no legislative framework guiding contract farming arrangements in Zimbabwe and there is also the question of whether farmers are knowledgeable on the prevailing policies protecting them considering the fact that most of them are new in the farming business. Also farmers may not be aware of how to handle breach of contracts from contractors because they don't know what the law says about it.

\section{CONCEPTUAL FRAMEWORK}


S.Afr. Tydskr. Landbouvoorl./S. Afr. J. Agric. Ext.,

Vol. 43, No. 2, 2015: $78-90$

DOI: http://dx.doi.org/10.17159/2413-3221/2015/v43n2a358
Odunze, Van Niekerk

\& Ndlovu.

(Copyright)

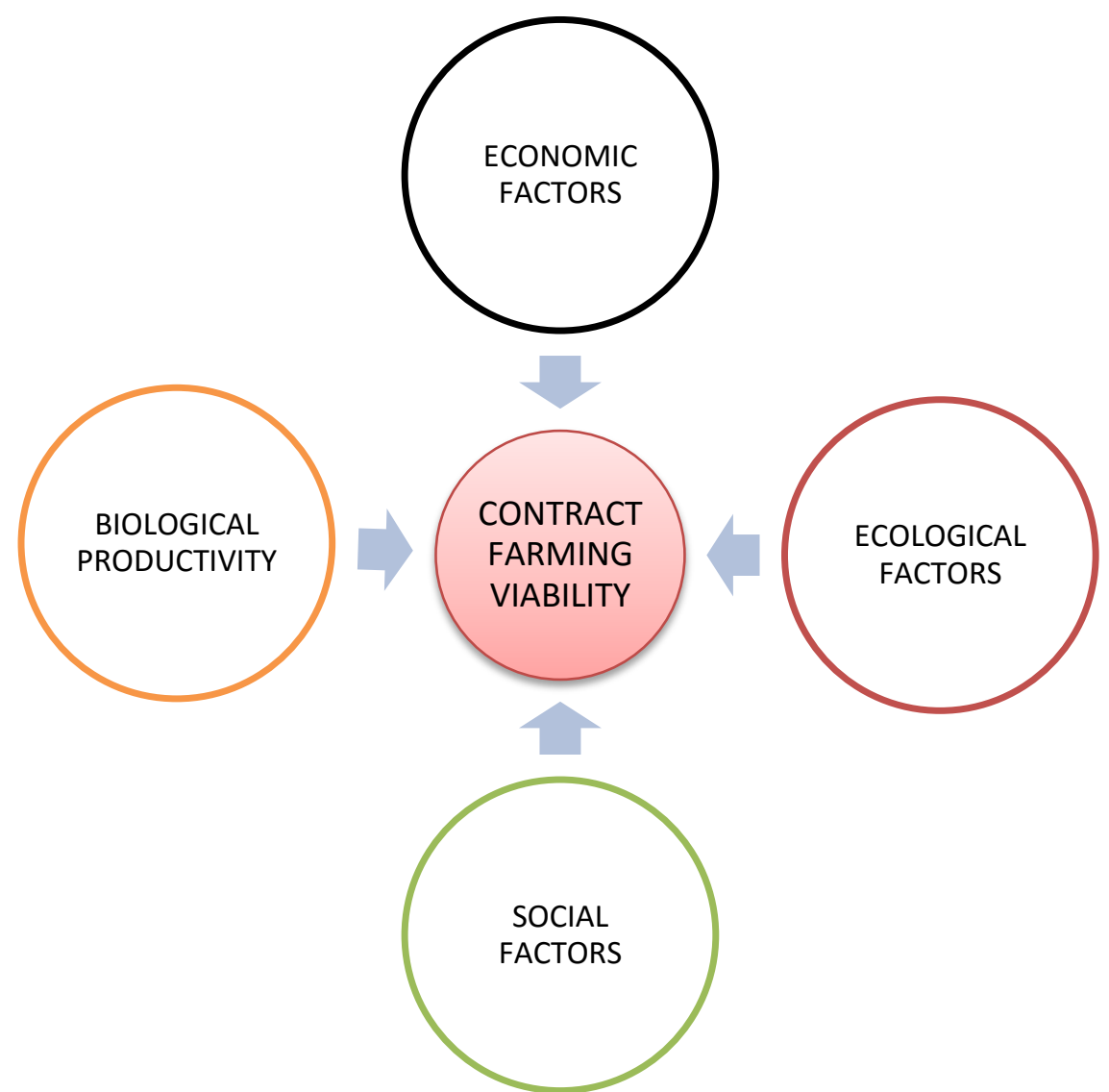

Figure 1.1: factors affecting contract farming viability in Zimbabwe

The paper assesses factors that affect viability of contract farming.

Viability of contract farming can be defined as the chances of success that contract farming has, given the factors surrounding it which involve social, economic, biological and environmental/ecological issues (Figure 1.1). Social factors include security of tenure, labour burden on the farmer, gender sensitive issues concerning who signs the contract in the family, bias towards large scale farms by contractors, literacy level of farmers and group dynamics that exist in farmers organizations. Under social factors there are also ethical issues which involve contractual default by both parties. There is a problem when both parties do not feel any ethical compulsion towards fulfilling their contractual obligations for example contractors failing to supply inputs on time or farmers side marketing produce.

Ecological/environmental factors involve suitability of a particular area for production of the specific crop which has to be addressed by both farmers and contractors. Suitability is defined in terms of rainfall amount and pattern, soil type, accessibility of the place and road network. Farming practices that are environmentally friendly have to be promoted by contractors to make sure that farmers implement them when producing the contracted crop. All these need to be discussed by all stakeholders involved in contract farming.

Economic factors involve the cost of running the contract farming venture in Zimbabwe. Lack of financing from banks and other credit institutions, the prevailing interest rates being charged by banks to contractors on loans, low profit levels of both parties due to high cost of 
S.Afr. Tydskr. Landbouvoorl./S. Afr. J. Agric. Ext., Vol. 43, No. 2, 2015: $78-90$

DOI: http://dx.doi.org/10.17159/2413-3221/2015/v43n2a358
Odunze, Van Niekerk

\& Ndlovu.

(Copyright)

production, unclear purchase arrangement and terms of payment between farmers and contractors are all factors that needs to be critically looked at in order to understand their impact on the viability of contract ventures. Chances also are that farmers might not be aware of prevailing market prices and trends, existing markets for their products, and other relevant information that will guide their decision making are very high given the limited access to information as they are in the rural areas. This then leaves the farmers at the mercies of contractors, some of whom are unscrupulous. Without information, the farmers bargaining power is greatly reduced.

Biological productivity involves mainly issues that arise under the productivity factor such as suitability of selected farmers in terms of farming experience, past production records and scale, timely provision of material inputs and technical support by contractors and timing of operations by farmers. There have been cases of farmers being contracted for production of crops they know nothing about and also cases of contractors disappearing after contracting the farmers only to show up during harvest without having provided any form technical support to the farmers. There is a need to understand how all this affects the viability of the contract farming venture

\subsection{Research objective}

To analyze how key business- related social, ethical, environmental and economic factors are being managed and built into this strategy in order to ensure its sustainability.

\subsection{Research question}

What are the social, ethical, biological, economic and physical factors impacting on the success of the contract farming strategy?

\section{METHODOLOGY}

\subsection{Description of study area}

This study was carried out in Mashonaland west and Mashonaland central provinces in Zimbabwe. Mashonaland West province covers a land area of $57,441 \mathrm{~km}^{2}$ and has a population of approximately 1.2 million. It is divided into six districts; Chinhoyi, Chegutu, Hurungwe, Kadoma, Kariba, Makonde, Zvimba (en.wikipedia.org). Mashonaland Central province covers an area of $28,347 \mathrm{~km}^{2}$ with a population approximating to 1 million people. It is divided into seven districts with Bindura, Centenary, Guruve, Mount Darwin, Rushinga, Shamva, and Mazowe (en.wikipedia.org). Both provinces fall under Natural region II with average annual rainfall at $700-1050 \mathrm{~mm}$ per year confined to the summer. Zimbabwe is divided into five broad Natural Regions which are classified according to rainfall amount, the land resource quality declines from natural region I through to region V. Natural region II occupies $15 \%$ of the Zimbabwean land area and accounts for $75-80 \%$ of the area planted to crops in Zimbabwe (FAO, 2006). The region is appropriate for intensive crop farming and livestock production (Gambiza \& Nyama 2000). Agricultural production is dominated by tobacco, cotton, maize, soya beans, horticultural activities and livestock rearing and these usually perform well given the rainfall amounts $(700-1050 \mathrm{~mm})$ received per year. Contract faming is very common and several companies which include Grain Marketing Board (GMB), Windmill, Kurima Gold promote maize and soya bean production mainly for stock feed through contract farming with smallholder farmers in the province. The main economic activities in the provinces are gold and nickel mining. 
S.Afr. Tydskr. Landbouvoorl./S. Afr. J. Agric. Ext.,

Vol. 43, No. 2, 2015: $78-90$

DOI: http://dx.doi.org/10.17159/2413-3221/2015/v43n2a358
Odunze, Van Niekerk

\& Ndlovu.

(Copyright)

\subsection{Data collection and analysis}

A simple random technique was used to select 70 farmers out of the excess of 150 who were contracted under maize and soya bean production by the two contracting companies Windmill and Kurima Gold. Four managers (two from each company) and ten staff members (five each) from the contracting companies were engaged cutting across the occupational divide of strategic management, tactical management and operations staff. Five Agriculture Extension and Technical Service (AGRITEX) officers, five Grain Marketing Board staff and two farmer representatives from Zimbabwe Farmers Union (ZFU) and Agriculture Marketing Authority (AMA) were also engaged in the study to provide a holistic view of the contract farming venture.

Data was collected through use of structured questionnaire which had been subjected to pretest. The variables of the study included social factors which are tenure security, preferred gender, literacy level, existence of farmer groups, labour burden on family, farmer experience and age; ecological factors were crop type and production practices; economic factors were access to bank loans, availability of credit, production costs, scale of operation, interest rates and terms of payment and lastly management factors which are literacy level, management commitment, level of experience and business strategies. A probit analysis was used to identify factors viable to the success of contract farming.

\section{RESULTS AND DISCUSSION}

A probit analysis was carried out in order to identify the factors that are significant to contract farming viability. Two binary models are presented with key factors that influence viability as the causal variables. This is done from both the farmers as well as the contractors' perspective. Odds ratios of both models are interpreted and comments are made on the factors which are significant in both models.

Many factors were assessed and a few found to affect viability of contract farming. Social factors included possession of title deeds, increased labour burden with contract farming, preference of male farmers, preference of literate farmers, preference of farmers belonging to farmer groups and of large scale farmers. Ecological factors entailed suitability of production area, use of fertilizers and pesticides, use of sustainable agriculture practices, trainings on sustainable practices and sustainable practices implemented. Biological factors assessed were farmers' years of experience, inputs availability, timely provision of the inputs, timeliness of farming operations, scale of operations, farmers' skills and knowledge and technical support from contractors. Willingness of banks to lend, interest rates charged by banks, pricing system of produce, profits realized, timeliness of payment of farmers by contractors and method of payment make up the economic factors.

From the probit analysis, only the following factors were found to impact significantly on the viability of maize and soya contract farming:

\subsection{Social Factors}


S.Afr. Tydskr. Landbouvoorl./S. Afr. J. Agric. Ext.,

Vol. 43, No. 2, 2015: $78-90$

DOI: http://dx.doi.org/10.17159/2413-3221/2015/v43n2a358

Table 1: Social factors

\begin{tabular}{|l|l|l|l|}
\hline FACTOR & RESPONDENTS & $\begin{array}{l}\text { ODDS } \\
\text { RATIO }\end{array}$ & INTERPRETATION \\
\hline $\begin{array}{l}\text { MEMBERSHIP OF } \\
\text { FARMER GROUP }\end{array}$ & FARMERS & 7.013 & $\begin{array}{l}\text { Being a member of a farmer's } \\
\text { association increases the chance of } \\
\text { viability by about } 7 \text { times }\end{array}$ \\
\hline $\begin{array}{l}\text { CONTRACTING } \\
\text { EXPERIENCE } \\
\text { EXPERIENCE }\end{array}$ & CONTRACTOR & 3.933 & $\begin{array}{l}\text { Each additional year of contracting } \\
\text { experience increases the chance of } \\
\text { viability by about } 4 \text { times }\end{array}$ \\
\hline FARTRACT & 3.092 & $\begin{array}{l}\text { Each additional year of contact } \\
\text { experience increases the chance of } \\
\text { viability by } 3 \text { times }\end{array}$ \\
\hline
\end{tabular}

Years of contract farming experience were found to impact significantly on viability of maize as they give the contractor confidence to work with the farmer. The odds ratio for contract experience for farmers' perspective was 3.092 meaning that each additional year of the farmer's contract experience increases the chance of viability by 3 times. According to the contractor's perspective odds ratio was 3.933 indicating that an additional year of contract farming experience increases the chance of viability by 4 times.84.9\% of the farmers have been producing under contract for less than 5 years while $9.1 \%$ have been producing under contract for more than 5 years. 100\% of the contractors have been in the business for less than 5 years. This means that the contractors and the farmers are both relatively new in the contract farming business. New comers in contract farming need more training whereas less time is taken training those that have done it before. In this study however farmers involved have an education with at least grade seven qualification, with $35 \%$ of them being diploma holders and 32\% bachelor's degree holders. Their level education makes them fully aware of product quality requirements, loyalty to contractual agreements and every condition set in the contract.

Membership of farmer's association was also found to impact significantly on the viability of contract farming, the odds ratio for this factor is 7.013 and this means that being a member of a farmer's association increases the chance of contract farming viability by about 7 times. $70.1 \%$ of the farmers agreed that contractors prefer to deal with farmers who are members of a farmer association. Contractors prefer dealing with groups because it is easier to manage. Farmers on the other hand are able to bargain better as a group than as individuals. Cairns Foods in the soya beans production in Zimbabwe was cited as having a contract structure that puts emphasis on group organization. This system makes it easier for the contractors to manage and control all the activities of the smallholder farmers (Minot 2011).

Farmer associations are essential for the empowerment and advancement of farmers. They strengthen the political power of farmers by increasing the likelihood of their voice being heard by policy makers and the public (Penunia, 2011). Dealing with farmers belonging to such associations is important as they are likely to understand contractual agreements and even be confident enough to suggest ways of improving them. 
S.Afr. Tydskr. Landbouvoorl./S. Afr. J. Agric. Ext.,

Vol. 43, No. 2, 2015: $78-90$

DOI: http://dx.doi.org/10.17159/2413-3221/2015/v43n2a358
Odunze, Van Niekerk

\& Ndlovu.

(Copyright)

\subsection{Ecological Factor}

Table 2: Ecological factors

\begin{tabular}{|l|l|l|l|}
\hline FACTOR & RESPONDENTS & $\begin{array}{l}\text { ODDS } \\
\text { RATIO }\end{array}$ & INTERPRETATION \\
\hline CROPS GROWN & FARMERS & 3.142 & $\begin{array}{l}\text { Soya bean is thrice more likely to increase } \\
\text { viability than maize }\end{array}$ \\
\hline CROPS GROWN & CONTRACTORS & 5.721 & $\begin{array}{l}\text { Contracting soya bean s increases the chance } \\
\text { of viability by 5 times more than maize }\end{array}$ \\
\hline $\begin{array}{l}\text { PRODUCTION } \\
\text { AREA }\end{array}$ & FARMERS & 2.067 & $\begin{array}{l}\text { Farmers in Mashonaland West are twice } \\
\text { more likely to increase viability than } \\
\text { Mashonaland Central }\end{array}$ \\
\hline PRODUCTION & CONTRACTORS & 6.927 & $\begin{array}{l}\text { Contracting one more farmer in Mash West } \\
\text { increases the chance of viability by almost 7 } \\
\text { times as compared to Mash Central. }\end{array}$ \\
\hline
\end{tabular}

The type of crop grown is a viable productivity factor towards contract farming. According to the probit analysis, the odds ratio for type of crop grown is 3.141 for the farmers and 5.721 for the contractors. This means that the growing of soya beans is three times more likely to increase contract farming viability for the maize than the growing of maize and five times more likely to increase viability for the contractors than maize.59\% of the farmers interviewed are contracted to produce only maize, $16.4 \%$ produce soya beans and $23.9 \%$ grow both crops for contractors. $14.3 \%$ of the contractors contract farmers for soya production while $85.7 \%$ contract both crops. It is important to note than none of the contractors contracts for maize only. This is because higher profits are earned from soya beans than from maize. Contractors therefore contract farmers for either only soya beans or for both crops. Soya bean is a high value crop and is an important source of protein for both livestock and human populations. It is used to produce a variety of marketable products like soymilk, flour, yoghurt and in oil expression. Approximately $95 \%$ of soya bean produced in Zimbabwe goes to the processing industry for the production of soya bean oil and then soya bean cake the by-product of oil extraction is used for manufacturing feed.

Production area is another factor which was found to increase viability of contract farming. The odds ratio for the farmers is 2.067 and 6.927 for the contractors on production area. This means that farmers in Mashonaland West are twice more likely to increase viability than Mashonaland Central. 53\% of the farmers contracted for maize and soya production are from Mashonaland West while $47 \%$ are from Mashonaland Central. Geographic location has implications on monitoring and control therefore contractors do not only seek suitable growers but also a suitable community environment.

\subsection{Biological productivity factor}


S.Afr. Tydskr. Landbouvoorl./S. Afr. J. Agric. Ext.,

Vol. 43, No. 2, 2015: $78-90$

DOI: http://dx.doi.org/10.17159/2413-3221/2015/v43n2a358
Odunze, Van Niekerk

\& Ndlovu.

(Copyright)

Table 3: Biological productivity factors

\begin{tabular}{|l|l|l|l|}
\hline FACTOR & RESPONDENT & $\begin{array}{l}\text { ODDS } \\
\text { RATIO }\end{array}$ & INTERPRETATION \\
\hline FARMING SCALE & FARMERS & 2.067 & $\begin{array}{l}\text { Farmers in Mashonaland West are twice } \\
\text { more likely to increase viability than } \\
\text { Mashonaland Central }\end{array}$ \\
\hline FARMING SCALE & CONTRACTORS & 6.492 & $\begin{array}{l}\text { Contracting one additional large scale } \\
\text { farmer increases the chance of viability by } \\
\text { about } 6 \text { times }\end{array}$ \\
\hline $\begin{array}{l}\text { FARMER'S YEARS } \\
\text { OF EXPERIENCE }\end{array}$ & CONTRACTORS & 3.753 & $\begin{array}{l}\text { Each additional year of experience of the } \\
\text { contractor would increase the chances of } \\
\text { viability by about 3 times more }\end{array}$ \\
\hline INPUTS & FARMERS & 4.028 & $\begin{array}{l}\text { One more set of inputs availed to farmers } \\
\text { increases the chances of viability by } \\
\text { almost 4 times }\end{array}$ \\
\hline INPUTS & CONTRACTORS & 2.191 & $\begin{array}{l}\text { Each additional set of material inputs } \\
\text { would increase the chance of viability by } \\
\text { about twice as much as when they are not } \\
\text { availed }\end{array}$ \\
\hline
\end{tabular}

Scale of production is an important factor in contract farming and according to the probit analysis, the odds ratio for type of scale of farming is 7.045 for the farmer and 6.492 for the contractor. This means that large scale farming is seven times more likely to increase viability than small scale farming for a farmer and contracting a large scale farmer increases viability by six times for a contractor. $95.5 \%$ of the farmers agreed to the fact that contractors prefer large scale farmers. This is line with Runsten (1992) who argued that larger growers are likely to be more attractive partners to contractors. The reason is because the costs incurred by contractors are lower per unit of output and quality are better managed by large growers. Most contractors have also faced challenges working with smallholder farmers due to low yields, poor quality because of inadequate resources, poor management and side marketing hence they prefer large scale farmers (Maunze, 2010). 71.4\% of contractors interviewed contract medium scale farmers while $28.6 \%$ of contractors contract small scale farmers and this shows the preference of bigger scale of production.

Farmer's years of experience falls under both social and biological productivity factors. From the probit analysis, the odds ratio for type of farmers experience is 3.092. This means that each additional year of experience for farmers increases viability of the venture by three times. $94 \%$ of the farmers agreed that years of experience affects yield that they obtain. It can 
S.Afr. Tydskr. Landbouvoorl./S. Afr. J. Agric. Ext.,

Vol. 43, No. 2, 2015: $78-90$

DOI: http://dx.doi.org/10.17159/2413-3221/2015/v43n2a358
Odunze, Van Niekerk

\& Ndlovu.

(Copyright)

be concluded that working with farmers that are not new in the farming venture is better as contractors can bank on their years of experience to make production decisions that will lead to higher yields.

Material input availability which is a productivity factor was also found to be a significant factor. From the probit analysis, the odds ratio for material input availability is 2.191 for contractors and 4.028 for farmers. This means that each set of material inputs availed increases the chance of viability twice for contractors and four times for farmers. The importance of inputs cannot be over emphasized because without them there is no production. $100 \%$ of the farmers agreed to the importance of availability of inputs. This explains why contractors provide inputs as part of contractual agreements and provide them in good time for the convenience of farmers. This is in line with Minot (2011) argument that when the degree of input support is not sufficient, there is a high possibility of venture failure.

\subsection{Economic Factor}

Table 4: Economic factors

\begin{tabular}{|l|l|l|l|}
\hline FACTOR & RESPONDENT & $\begin{array}{l}\text { ODDS } \\
\text { RATIO }\end{array}$ & INTERPRETATION \\
\hline $\begin{array}{l}\text { ACCESS TO } \\
\text { LOANS }\end{array}$ & FARMERS & 5.211 & $\begin{array}{l}\text { An additional bank that is willing to } \\
\text { extend credits to farmers would } \\
\text { increase the chances of viability by } \\
\text { about 5 times more }\end{array}$ \\
\hline $\begin{array}{l}\text { ACCESS TO } \\
\text { LOANS }\end{array}$ & CONTRACTORS & 5.211 & $\begin{array}{l}\text { An additional bank that is willing to } \\
\text { extend credits to farmers would } \\
\text { increase the chances of viability by } \\
\text { about 5 times more }\end{array}$ \\
\hline
\end{tabular}

Access to finances is a contributor to success of any enterprise but with rural farmers there are many challenges hindering them. The willingness of banks to lend to farmers is an economic factor which adds viability towards contract farming. From the probit analysis, the odds ratio for willingness of banks to lend money to farmers is 5.211 for both farmers and contractors. This means that each additional bank that is willing to lend to farmers would increase viability by about five times if the farmer is under contract farming. $83 \%$ of the farmers say banks are willing to lend them if they are under contract farming. Banks require collateral to show security against loans that is why it becomes difficult to lend small scale farmers however if they are involved in contract farming they stand a better chance.

Two social, one economic and two ecological and three biological productivity factors were found to be significant to the viability of contract farming from the probit analysis, therefore the null hypothesis that social, ecological, biological and economic factors have no impact on the viability of maize and soya contract farming is rejected.

\section{CONCLUSIONS AND RECOMMENDATIONS}


S.Afr. Tydskr. Landbouvoorl./S. Afr. J. Agric. Ext.,

Vol. 43, No. 2, 2015: $78-90$

DOI: http://dx.doi.org/10.17159/2413-3221/2015/v43n2a358
Odunze, Van Niekerk

\& Ndlovu.

(Copyright)

The research was undertaken to analyse the viability of contract farming as a market development strategy in the maize and soya sector of Zimbabwe through a mixed method approach. The strength of the approach was that it allowed both quantitative and qualitative data to be obtained, analysed and interpreted to give a balanced analysis of the contract venture. According to the probit analysis it can be concluded that factors increasing the viability of contract farming include contract farming experience, type of crops grown, and production area, farming scale, inputs availability, farming experience, technical support and access to finances. Maize and soya bean contract farming in Mashonaland west and central provinces in Zimbabwe has potential for growth. There is a need for both farmers and contractors to understand the factors that influence viability of contract farming. Both farmers and contractors have a big role towards the success of these factors in contract farming through effective planning. Commitment and participation of all stakeholders is a major requirement for the success of the venture.

The findings in this paper offer a platform for improvement of future contract farming ventures in Zimbabwe. Recommendations for the involved parties are:

\section{Contractors}

Engagement of extension staff in contract farming is essential for its future improvement as they are the key link between contractors and farmers. Contractors must therefore liaise with extension staff prior to initiation of contracts and educate farmers so as to prepare them for the project. Extension staff will then monitor progress throughout the farming season and farmers will be able to report locally any challenges for example pest and disease attack. This kind of technical assistance and close monitoring will improve quality of farmers' produce. It may reduce cases of side marketing produce or diverting inputs for other uses by farmers. Both parties need to honour contractual agreements at all costs. Timely provision of inputs, timely payment by contractors and timely collection of harvest is necessary for a successful venture. Contractors must have adequate information on production area in relation to the crop being produced for the contract to avoid risks of the crop failing because of climatic conditions. It is also recommended for management to organize relevant training programmes for both extension staff and farmers to familiarize them with their projects.

\section{Farmers}

Farmers must seek enough information and understand terms of the contract before engaging into contract farming. They must then stick to contractual agreements despite the temptation to side market produce due to higher prices outside. Farmers should take advantage of such opportunities and learn new technical skills to produce high quality produce for the markets. Record keeping, knowledge of quality and demands of export markets and appropriate methods of applying chemicals and fertilizers are among some skills that farmers can acquire through participation in contract farming. It is recommended also for farmers to belong to farmer associations in their community as seen in the research findings as this impacts on the viability of contract farming.

\section{Extension staff}

Contract farming is a means of developing markets and technical skills in a way that is profitable to the farmer and the contractor. Extension staff has a role to fulfil in-order to ensure that farmers and contractors have knowledge on factors that affect viability of contract farming. They must possess a good comprehension of the crops or animals under the specific contract, effective communication skills to organize and administer cropping schedules and buying procedures fairly and honestly and be well versed with understanding of social 
S.Afr. Tydskr. Landbouvoorl./S. Afr. J. Agric. Ext.,

Vol. 43, No. 2, 2015: $78-90$

DOI: http://dx.doi.org/10.17159/2413-3221/2015/v43n2a358
Odunze, Van Niekerk

\& Ndlovu.

(Copyright)

customs, farming practices and language of communities they work with. This research will provide extension officers with the knowledge of what factors affect viability of contract ventures which they will not only pass on to the farmers and contractors but also help come up with strategies to manage them and minimize their effects. According to this research contractor's prioritized farmers' years of experience in contract farming ventures hence extension staff should be able to provide mentorship to farmers who are new so as to be obtain a good performance from them.

\section{Government}

The government must also play a role by creating a legal system and legislation to support small scale farmers involved in contract farming. Government can offer subsidies to contractors in the form of input subsidies. Contractors sometimes fail to access inputs on time due to financial difficulties and this often leads to delay in the timely delivery of inputs to farmers thereby compromising the whole contract farming venture. Access to subsidized inputs will go a long way in enabling contractors fulfil their contractual obligations which in the long term will increase the viability of contract farming and ensure its sustainability as a market development strategy.

\section{REFERENCES}

CLAPP, R. A. 1994. The moral economy of the contract. In Little, P. D. \& Watts, M. J. (Eds) Living Under Contract. Madison: University of Wisconsin Press

COSTAlES, A. C. \& CATELO, M. M. O. 2008. Contract Farming and Other Market Institutions as Mechanisms for Integrating Smallholder Livestock Producers in the Growth and Development of the Livestock Sector in Developing Countries. 2009. [Online] Available:www.fao.org/ag/ppli.html Accessed: 02 May 2015.

DAWES, M., MUROTA, R., JERA, R., MASARA, C. \& SOLA, P. 2009. Inventory For Small Holder Contract Farming In Zimbabwe. SNV Publications.

FAO. 2006. Fertilizer use by crop in Zimbabwe published by FAO, Rome, 2006

FAO. 2013. Contract farming for inclusive market access. FAO. Rome

GAMBIZA, J. \& NYAMA, .C. 2000. Country pasture/forage resource profiles. Country profiles, Zimbabwe. FAO Document.

KIRSTEN, J. \& K. SARTORIUS. 2002. Linking agribusiness and small-scale farmers in developing countries: is there a new role for contract farming? Development Southern Africa 19 (4): 503-529.

LITTLE, P. D. \& WATTS, M. 1994. Living under Contract. Madison. United States of America. University of Wisconsin Press

MASAKURE, O. \& HENSON, S. 2005. Why Do Small-Scale Producers Choose to Produce under Contract? Lessons from Non-traditional Vegetable Exports from Zimbabwe. World Development, 33(10), 1721-1733.

MAUNZE, S. 2010. Agro-dealers in Zimbabwe: scaling input provision as key for successful small farmer engagement, SNV Harare, 2012. http://www.snvworld.org/sites/www.snvworld.org/files/publications/3._soc_zimbabwe_a gro-inputs.pdf

MINOT, N. 2011. Contract farming in Sub-Sahara Africa. Opportunities and Challenges. IFPRI

NEPAD. 2008. East Africa Policy Brief No. 2: Contract Farming's Potential in Linking Smallholder Farmers to Market. www.Aiaee.Org/Attachments/093_Rivera-Evol-11-24.Pdf. 
S.Afr. Tydskr. Landbouvoorl./S. Afr. J. Agric. Ext.,

Vol. 43, No. 2, 2015: $78-90$

DOI: http://dx.doi.org/10.17159/2413-3221/2015/v43n2a358
Odunze, Van Niekerk

\& Ndlovu.

(Copyright)

PANDIT, A., PANDEY, N. K., RANA, R. K. \& LAL, B. 2009. An Empirical Study of Gains from Potato Contract Farming. Indian Journal of Agricultural Economics, 64(3), 497 508.

PARIRENYATWA, K. T. \& MAGO, S. 2014. Evolution and Development of Contract Farming in Zimbabwe: A Reflection for Agribusiness MCSER Publishing, Rome-Italy Vol. 5 No 20

PORTER, G. \& PHILLIPS-HOWARD, K. 1997. Comparing Contracts: An Evaluation of Contract Schemes in Africa. World Development, 25(2), 227 - 238.

PROWSE, M. 2012. Contract Farming in Developing Countries - A Review. February 2012. [Online] Available: www.recherche.afd.fr Accessed: 02 May 2015.

RUNSTEN, D., 1992. Transaction costs in Mexican fruit and vegetable contracting: Implications for association and participation. Paper Presented at the XVIII International Congress of the Latin American Studies Association, Atlanta.

SHOJA RANI, B. N. 2007. Globalisation and Contract Farming in India - Advantages and Problems. [Online] Available: www.iimahd.ernet.in/ Accessed: 02 May 2015.

SCOONES, I. 2012. Zimbabweland. www.allafrica.com.

PENUNIA, E. A., 2011. The Role of Farmers' Organizations in Empowering and Promoting the Leadership of Rural Women Expert, Asian Farmers Association for Sustainable Rural Development (AFA) Philippines.

WILL, M. 2013 A practical guide for linking small-scale producers and buyers through business model innovation, Contract farming handbook page 21 published by Deutsche Gesellschaft für Internationale Zusammenarbeit (GIZ) GmbH Bonn, Germany.

WOODEND, J. J. 2003. Potential of contract farming as a mechanism for the commercialization of smallholder agriculture - The Zimbabwe case study. FAO Report. Harare. Zimbabwe. 